\title{
Development Of Critical Thinking Disposition Inventory
}

\author{
I Wayan Redhana ${ }^{1}$, I Wayan Karyasa ${ }^{2}$, Ni Putu Fitria Atrisa ${ }^{3}$ \\ Department of Chemistry Education \\ Universitas Pendidikan Ganesha \\ Indonesia \\ redhana.undiksha@gmail.com ${ }^{1}$
}

\begin{abstract}
The aims of the study was to produce an inventory of critical thinking disposition. The inventory was used to measure critical thinking disposition of junior high school students. Model of the study was research and development. Stages of the study included (a) research and information collecting, (b) planning, (c) develop a preliminary form of product, and (d) preliminary field testing. The inventory was based on seven scales of critical thinking disposition of American Philosophy Association, including (a) truth-seeking consisting of five subscales, (b) open-mindedness consisting of three subscales, (c) analyticity consisting of eight subscales, (d) systematicity consisting of four subscales, (e) critical thinking self-confidence consisting of five subscales, (f) inquisitiveness consisting of two subscales, and (g) cognitive maturity consisting of six subscales. Results of expert validations and readability testing showed that, in general, the inventory being developed was very appropriate to measure the critical thinking disposition of students.
\end{abstract}

Keywords_-critical thinking; disposition; inventory

\section{INTRODUCTION}

Critical thinking is one of the most important thinking that is needed by everyone in solving problems and or making important decisions in daily life. Critical thinking is not a birth-gift and yet it needs to be developed throughout the life process. Critical thinking can be trained.

Critical thinking is necessary to solve problems and make decisions during school learning. Critical thinking is not only required by students at the higher level but is also needed at lower levels. In order the students to have the critical thinking, this critical thinking needs to be trained during the learning process by confronting students with challenging problems. These challenging issues are ill-structured and open-ended problems.

Critical thinking consists of two aspects. First is the attitude aspect and the second is the knowledge and skill aspect. This knowledge and skills of critical thinking are referred to as critical thinking abilities. The critical thinking abilities are often referred to as the critical thinking skills only. In the attitude aspect, this critical thinking is a critical thinking disposition. The critical thinking disposition is the soul or critical spirit that encourages a person to use the critical thinking skills. The results showed that critical thinking disposition affects critical thinking skills. Meanwhile, the disposition of critical thinking was a prerequisite for developing critical thinking skills [2].

The disposition of critical thinking can be interpreted as a tendency for a person to think critically. There are some experts who put forward the characteristics of critical thinking disposition, including (a) asking questions clearly and reasonably, (b) trying to understand others' ideas well, (c) using reliable sources, (d) taking into account the situation as a whole, (e trying to remain relevant to the underlying problem, (f) keeping to refer to the original problem, (g) looking for alternatives, (h) being open, (i) taking a position, (j) acting fast, (k) holding that something is part of a complex whole, (l) exploiting the critical thinking of others, and (m) being sensitive to the feelings of others [3]. Someone who has a critical thinking disposition tends to (1) make himself or herself convinced that his or her opinions and decisions are correct, (b) understand and respect someone clearly and candidly, and (c) care about others [4]. On the other hand, there is seven scales of critical thinking disposition, namely: (a) inquisitiveness (b) systematicity (c) analyticity, (d) openmindedness, (e) cognitive maturity, (f) truth-seeking, and (g) critical thinking (CT) self-confidence [5].

Someone may have the ability to think critically but does not tend to apply it [6]. Only someone who has the critical thinking disposition will use his critical thinking skills. Thus it can be said that the critical thinking disposition is a very important thing owned by students. By having a high critical thinking disposition, students will be able to use their critical thinking skills that can assist them in mastering the subject matter learned and solving problems encountered in everyday life. Along with that, scores of critical thinking disposition of students is very important to know. Therefore, an instrument is needed to measure the disposition score of students' critical thinking.

Some experts have developed several instruments to measure the disposition of critical thinking. One of the most commonly used measuring instruments is the California Critical Thinking Disposition Inventory (CCTDI) developed by the American Philosophy Association in Delphi Project in 1990 [5]. The disadvantages of using CCTDI in measuring critical thinking dispositions are that this inventory is expensive and uses English and Western cultural context so difficult to understand by the respondents when used to 
measure the disposition of critical thinking of students in Indonesia. Based on the description, it can be said that the development of inventory disposition of critical thinking is very important to do.

The inventory to measure the critical thinking disposition of students using Indonesian language and Indonesian cultural context has not been developed. This study will develop the critical thinking disposition inventory that can be used to measure students' critical thinking disposition.

\section{METHOD}

The study used research and development method [1]. The study only involved stages of research and information collecting, planning, develop the preliminary form of product, and preliminary field testing. The preliminary field testing involved an expert validation and readability testing.

\section{A. Research and information collecting}

At this stage, literature study and field study were conducted. The literature study was done by examining the documents related to the theory of inventory and scales/subscales of the critical thinking disposition. The field study was conducted through administrating questionnaires to teachers and students of junior high schools. The number of teachers and students involved in this study were 90 and 406, respectively. These teachers and students came from 10 junior high schools in Buleleng regency of Bali, namely SMPN 4 Tejakula, SMPN 1 Kubutambahan, SMPN 2 Sawan, SMPN 1 Singaraja, SMPN 4 Singaraja, SMPN 1 Sukasada, SMPN 1 Banjar, SMPN 1 Busungbiu, SMPN 1 Seririt, and SMPN 3 Gerokgak.

\section{B. Planning}

At this stage, the creation of a critical thinking disposition guideline was made. The making of this guideline involved determining the scales and subscale of critical thinking disposition, the number of statements, the nature of the statements, and the students' response format. This was done so that the inventory developed was right on target.

\section{Develop preliminary form of product}

At this stage, statement formulations were made for each subscale of critical thinking disposition. The formulations of statements consisted of positive and negative statements with almost equal numbers. This was so that students did not fill inventory on an arbitrary basis.

\section{Preliminary field testing}

Preliminary field testing included expert validation and readability testing. In the expert validation, the developed inventory was validated by two experts, i.e. psychologists and linguists. Both experts read and evaluated the inventory carefully and then gave inputs. These inputs were used to revise inventory.

The revised inventory was then tested for readability to the 10 students through focus group discussions. They read carefully it and try to understand the meaning of each statement. Statements that had not been understood well by students were presented to authors and then were revised.

\section{RESULTS AND DISCUSSION}

\section{A. Results of the study}

\section{Results of research and information collectiong}

The results of the literature study stage were the definition of critical thinking disposition, as well as scales and subscales of the critical thinking disposition according to some experts [4], [5], [7]. In the literature study stage, it was also obtained results about the cognitive development of junior high school students. The age of junior high school students is generally around 11-15 years. According to Piaget's theory, students over the age of 11 enter formal operational phase [8]. In this phase, a child can already think abstractly so it can be said that the critical thinking disposition inventory can be tested to junior high school students.

Results of questionnairy distribution to the teachers showed that most teachers had facilitated the development of students' critical thinking dispositions including (a) truthseeking, (b) open-mindedness, (c) analyticity, (d) systematization, (e) CT self-confidence, (f) inquisitiveness, and (g) maturity. Most of them also argued that it was important to make an instrument to measure the critical thinking disposition of junior high school students so that they can more easily assessed the critical thinking disposition of students.

The results of questionnairy distribution to the students showed that in general most students stated that they had developed a critical thinking disposition during the teaching and learning. The scales of critical thinking disposition developed by students were (1) truth-seeking, (2) openmindedness, (3) analyticity, (4) systematicity, (5) CT selfconfidence, (6) inquisitiveness, and (7) maturity.

\section{Scales and subscales of critical tihinking disposition}

Scales used to design the critcal thinking disposition inventory were ones being developed by American Philosophy Association dalam Delphi Project [5]. Meanwhile, subscales were made by modifying subscales developed by American Philosophy Association dalam Delphi Project [5]. All scales and subscales used to design the critical thinking disposition inventory were presented in Table 1 .

TABLE I. SKALA DAN SUBSKaLA INVENTORI DISPOSISI BERPIKIR KRITIS

\begin{tabular}{|c|c|c|}
\hline No. & Skalas & $\begin{array}{c}\text { Subskalas } \\
\end{array}$ \\
\hline 1. & Truth-seeking & $\begin{array}{l}\text { a. Tring to find out the truth clearly } \\
\text { b. Having spirit to ask questions } \\
\text { c. Being objective/honest toward information } \\
\text { d. Trying to understand something well } \\
\text { e. Using trusted sources }\end{array}$ \\
\hline 2. & $\begin{array}{l}\text { Open- } \\
\text { mindedness }\end{array}$ & $\begin{array}{l}\text { a. Considering other ideas in making their own } \\
\text { decisions } \\
\text { b. Being tolerant of the different ideas } \\
\text { c. Changing opinions when they were refuted } \\
\text { by strong facts/evidence }\end{array}$ \\
\hline 3. & Analyticity & $\begin{array}{l}\text { a. Being aware of the risks and possibilities that } \\
\text { will occur from an event } \\
\text { b. Being able to give a reason when faced with } \\
\text { complicated problems } \\
\text { c. Being able to provide objective evidence } \\
\text { against a particular problem }\end{array}$ \\
\hline
\end{tabular}




\begin{tabular}{|c|c|c|}
\hline & & $\begin{array}{l}\text { d. Being able to think logically } \\
\text { e. Estimating advantages and disadvantages of } \\
\text { phenomena } \\
\text { f. Being able to relate results of observation } \\
\text { with existing (knowledge) theories } \\
\text { g. Looking for alternative solutions of problems } \\
\text { h. Contemplating basic concepts that have been } \\
\text { understood }\end{array}$ \\
\hline 4. & Systematicity & $\begin{array}{l}\text { a. Thinking and acting in organized manner } \\
\text { b. Focusing on problems } \\
\text { c. Using inquiry methods to solve problems } \\
\text { d. Do not hurry to draw a conclusion from } \\
\text { information }\end{array}$ \\
\hline 5. & $\begin{array}{l}\text { CT self- } \\
\text { confidence }\end{array}$ & $\begin{array}{l}\text { a. Having confidence in his own opinion and } \\
\text { decisions } \\
\text { b. Believing on results of self-reasoning } \\
\text { c. Having confidence to lead other people to a } \\
\text { rational problem solving } \\
\text { d. Daring to take action or a decision } \\
\text { e. Being proud of your own abilities to solve } \\
\text { problems }\end{array}$ \\
\hline 6. & Inquisitiveness & $\begin{array}{l}\text { a. Having a high learning spirit even when the } \\
\text { application of the studied science has not } \\
\text { been seen directly } \\
\text { b. Having spirit to learn new things }\end{array}$ \\
\hline 7. & $\begin{array}{l}\text { Cognitive } \\
\text { maturity }\end{array}$ & $\begin{array}{l}\text { a. Do not get rid of problems } \\
\text { b. Realizing that some problems are related to } \\
\text { each other } \\
\text { c. Realizing that an assessment must be based } \\
\text { on criteria } \\
\text { d. Avoiding actions that confuse /intimidate } \\
\text { others with critical thinking skills possessed } \\
\text { e. Showing calm in thinking } \\
\text { f. Understanding other people's way of } \\
\text { thinking }\end{array}$ \\
\hline
\end{tabular}

\section{Draft of inventory}

Based on the data in Table 1, it could be seen that the total number of subscales used to construct a critical thinking disposition inventory was 33 items. On each subscale, it was made two corresponding statements, one positive statement and another negative statement. The responses to each statement were based on the Likert scale, i.e. : strongly disagree (score 1), disagree (score 2), neutral (score 3), agree (score 4), and strongly agree (score 5). The development result was a draft of critical thinking disposition inventory.

\section{Results of preliminary field testing}

The results of validation by psychologists showed that the selected scales and subscales were appropriately used to measure the critical thinking disposition. In addition, the validation results showed that there was a relationship among the scales, subscales, and statements used in the inventory. Meanwhile, the results of validation by linguists, in general, showed that most of the statements listed were appropriate and had a clear meaning.

Results of readability testing showed that most statements of the critical thinking disposition could be understood by students. However, there were some words being not understood by students, for example: "alternatif (alternative)," "pilihan (option)," “terorganisir (organized)," and "insting (instinct)." Authors revised those words.

\section{B. Discussion}

The critical thinking disposition is an attitude that can help students to master the subject matters well. A person can have critical thinking skills but does not tend to use them [6]. Only people who have a critical thinking disposition will attempt to use their critical thinking skills.

Students having the critical thinking dispositions in the term of truth-seeking and open-mindedness always try to know and understand information clearly, take into account others' opinions and be flexible with their own stance. Openmindedness is not only about how we accept others' views who are different from what we have, but also about how we can accept if others can think of something more than us or if our own opinions may be wrong [9]. This attitude helps students during the learning process to understand and explore subject matters being learnt.

Students having the critical thinking disposition in term of analyticity have a tendency to be cautious about what will happen. This can help students analyze the consequences of good or bad situations, choices, or plans. In addition, students also tend to be accustomed to ponder the basic concepts that have been studied carefully and can relate the theory that he learned with the events he encountered in everyday life.

Students having a critical thinking disposition in the term of cognitive maturity tend to face the problems thoroughly. This familiarizes the students with responsibility for the problems to be solved. Based on the description, it can be concluded that the critical thinking disposition is very useful for students, especially in helping students to have the spirit of learning and achievement motivation, and understand and master the subject matters. Students having the critical thinking disposition have the attitude, the spirit, or the motivation to use and develop their thinking skills so they can improve the mastery over the subject matters.

The inventory of critical thinking disposition will help teachers to provide information about the critical thinking dispositions of students, both instantaneously [2], [10], [11], [12], [13], [14], and periodically [15], [16], [17], [18]. By providing this information, teachers can design appropriate learning strategies to improve students' critical thinking disposition. Related to this, it had been developed various learning strategies to improve the critical thinking disposition of students, namely: guided reciprocal peer questioning [19], microteaching [20], technology facilitated problem based learning pedagogy [21], infusion approach [22]. The critical thinking disposition had been investigated strongly in relation to emotional intelligence skill [23], self-efficacy [24], students' learning styles [25], students' performances [26]. Meanwhile, the critical thinking dispositions encourage students to develop dialogue skills [27]. Even, the critical thinking disposition can be used to predict the success of students in practicum [24].

Some researchers had developed the inventory of critical thinking disposition by modifying California Critical Thinking Disposition Inventory [7], [28]. This is done in order to provide an instrument for measuring the critical thinking disposition of students in which this disposition is essential for developing the critical thinking skills of students. 


\section{CONCLUSION}

Characteristics of inventory developed used seven critical disposition scales: (1) truth-seeking, (2) open-mindedness, (3) analyticity, (4) systematicity, (5) CT self-confidence, (6) inquisitiveness, and (7) cognitive maturity.

The validation results of psychologist and linguist showed that the critical thinking disposition inventory developed was appropriate for measuring the students' critical thinking disposition. The results of the readability testing showed that in general the inventory of critical thinking disposition developed was well understood by the students.

Based on the results of this study, it can be suggested that this inventory needs to be further empirically tested to determine the validity of the items and the reliability of the instrument. With the fulfillment of item validity and instrument reliability, this inventory can be used to measure students' critical thinking disposition.

\section{ACKNOWLEDGMENT}

The authors express the highest gratitude and appreciation to the headmasters of junior high schools who have allowed authors to collect data in their schools. Acknowledgments are also conveyed to the parties who participated in helping the authors so that this study can be carried out smoothly.

\section{REFERENCES}

[1] W. R. Borg and M. D. Gall, Educational Research: An introduction, $5^{\text {th }}$ ed. New York: Longman, Inc., 1989.

[2] F. Ojowole and C. Thompson, "Assessment of critical thinking dispositions of nursing students in southwestern Nigeria," Int. J. Res. Applied, Nat. Soc. Sci., vol. 2, no. 3, pp. 7-16, 2014

[3] Sumarno, "Pembinaan karakter, berpikir dan disposisi matematik, kesulitan guru dan siswa serta alternatif solusinya," in Seminar Pendidikan Matematika di UNINUS, 2011

[4] R. H. Ennis, "Critical thinking dispositions: their nature and assessability," Informal Log., vol. 2, no. 3, pp. 165-182, 1996.

[5] P. A. Facione, C. A. Giancarlo, and N. C. Facione, "The disposition toward critical thinking," J. Gen. Educ., vol. 44, no. 1, pp. 1-25, 1995

[6] P. A. Facione, "Critical thinking: What it is and why it counts," 2011 [Online]. Available: http://site. insightassessment.com/content/download/789/4985/file/Disposition_to _CT_1995_JGE.pdf. [Accessed: 12-Dec-2015].

[7] J. C. Ricketts, "The efficacy of leadership development, critical thinking dispositions, and student academic performance on the critical thinking skills of selected youth leaders," University of Florida, 2003.

[8] J. W. Santrock, Educational psychology, $5^{\text {th }}$ ed. New York: The McGraw Hill Company, Inc., 2011.

[9] T. Carrol, "Sikap Seorang Pemikir Kritis," 2004. [Online]. Available: http://www.faktailmiah. com/2010 /06/27/sikap-seorang-pemikir-kritisberpikiran-terbuka-skeptis-dan-tentatif.html.

[10] J. T. Broadbear, G. Jin, and T. J. Bierma, "Critical thinking disposition among undergraduate students during their introductory health education course," Heal. Educ., vol. 37, no. 1, pp. 8-15, 2005.

[11] R. C. Feng, M. J. Chen, M. C. Chen, and Y. C. Pai, "Critical thinking competence and disposition of clinical nurses in a medical center," $J$. Nurs. Res., vol. 18, no. 2, pp. 77-78, 2010. paedagofy

[12] S. Ozkahraman and B. Yildirim, "Investigation of critical thinking disposition in a university hospital of nurses working in Turkey," Int. J. Appl. Sci. Technol., vol. 2, no. 3, pp. 143-149, 2012.
[13] A. C. Biber, A. Tuna, and L. Incikabi, "An investigation of critical thinking dispositions of mathematics teacher candidates," Educ. Res. vol. 4, no. 2, pp. 109-117, 2013.

[14] E. Demirhan and N. Koklukaya, "The critical thinking dispositions of prospective science teachers," Procedia - Soc. Behav. Sci., vol. 116, pp. 1151-1155, 2013.

[15] L. M. Carter, "Critical thinking dispositions in online nursing education," J. Distance Educ., vol. 22, no. 3, pp. 89-114, 2008.

[16] R. M. Cisneros, "Assessment of in critical thinking pharmacy students," Am. J. Pharm. Educ., vol. 74, no. 4, pp. 1-7, 2009.

[17] L. Incikabi, A. Tuna, and A. C. Biber, "An analysis of mathematics teacher candidates' critical thinking dispositions and their logical thinking skills," J. Int. Educ. Res., vol. 93, no. 257-266, 2013.

[18] H. Kaya, E. Senyuva, and G. Bodur, "Developing critical thinking disposition and emotional intelligence of nursing students: a longitudinal research," Nurse Educ. Today, vol. 48, pp. 72-77, 2017

[19] M. K. Meibodi, S. Lakdizaji, F. Abdollahzadeh, H. Hassankhanih, A Rahmani, and K. Lasater, "Impact of guided reciprocal peer questioning on the disposition of critical thinking among nursing students," Thrita J. Med. Sci., vol. 2, no. 3, pp. 100-114, 2013.

[20] Z. Arsal, "The effects of microteaching on the critical thinking dispositions of pre-service teachers," Aust. J. Teach. Educ., vol. 40, no. 3, pp. 109-117, 2015.

[21] W. C. W. Yu, C. C. Lin, M. H. Ho, and J. Wang, "Technology facilitated pbl pedagogy and its impact on nursing student's academic achievement and critical thinking dispositions," Turkish Online J. Educ. Technol., vol. 14, no. 1, pp. 97-107, 2015.

[22] N. M. Darby and A. M. Rashid, "Critical thinking disposition: the effects of infusion approach in engineering drawing," J. Educ. Learn., vol. 6 , no. 3 , pp. 203-311, 2017.

[23] N. L. P. Stedman and A. C. Andenoro, "Identification of relationships between emotional intelligence skill \& critical thinking disposition in undergraduate leadership students," J. Leadersh. Educ., vol. 6, no. 1 pp. 190-208, 2007.

[24] G. Yuksel and B. Alci, "Self-efficacy and critical thinking dispositions as predictors of success in school practicum," Int. Online J. Educ. Sci. vol. 4, no. 1, pp. 81-90, 2012

[25] H. C. Pai and C. J. Eng, "The relationships among critical thinking disposition, caring behavior, and learning styles in student nurses," Open J. Nurs., vol. 3, pp. 249-256, 2013.

[26] H. A. Mohamed and S. S. Mohammed, "Relationship between critical thinking disposition of nursing Studentsand their performance for patients on haemodialysis," IOSR J. Nurs. Heal. Sci., vol. 5, no. 6, pp 45-53, 2016.

[27] M. Neyestani, M. Heydari, and A. Ghamarani, "Relationship between critical thinking dispositions and dialogue-based education among teachers," J. Am. Sci., vol. 8, no. 8, pp. 704-708, 2012.

[28] E. Demircioglu and S. Kilman, "An adaptation study of critical thinking disposition scale,” Int. J. Soc. Sci., vol. 27, pp. 203-218, 2014. 